\title{
Manouchehr Moshtagh Khorasani [Manūčehr Moštāq Horāsānī]. Persian Archery and Swordsmanship. Historical Martial Arts of Iran
}

\section{Iván Szántó}

\section{(2) OpenEdition \\ 1 Journals}

\section{Electronic version}

URL: http://journals.openedition.org/abstractairanica/42205

DOI: 10.4000/abstractairanica.42205

ISSN: 1961-960X

Publisher:

CNRS (UMR 7528 Mondes iraniens et indiens), Éditions de l'IFRI

\section{Electronic reference}

Iván Szántó, « Manouchehr Moshtagh Khorasani [Manūčehr Moštāq Horāsānī]. Persian Archery and Swordsmanship. Historical Martial Arts of Iran », Abstracta Iranica [Online], Volume 34-35-36 | 2017, document 20, Online since 30 July 2017, connection on 26 September 2020. URL : http:// journals.openedition.org/abstractairanica/42205; DOI : https://doi.org/10.4000/abstractairanica 42205

This text was automatically generated on 26 September 2020 .

Tous droits réservés 


\title{
Manouchehr Moshtagh Khorasani [Manūčehr Moštāq Ȟrorāsānī]. Persian Archery and Swordsmanship. Historical Martial Arts of Iran
}

\author{
Iván Szántó
}

\section{REFERENCES}

Manouchehr Moshtagh Khorasani [Manūčehr Moštāq Horāsānī]. Persian Archery and Swordsmanship. Historical Martial Arts of Iran. Frankfurt a. M., Niloufar Books, 2013, 392 p., over 650 ill., 50 colour pl.

This monumental volume constitutes the most significant recent contribution, written in a Western language, to the study of the theory and practice of classical Persian chivalry. Its impressive thematic and illustrative breadth are explained by the fact that the book is the work of an eminent practitioner of traditional Persian martial arts, or razm-afzār, a peculiarity which not only offers a new perspective to this quasi-obsolete subject but also accounts for the personal tone occasionally permeating the text. As stated in its preface, the author's principal motivation for the completion of the book was the hope that by restoring the broken continuity of the age-old techniques and morality of razm-afzār, it can help reviving their tradition. Compared to his previous compendia (especially Arms and Armor from Iran: The Bronze Age to the End of the Qajar Period, Tübingen, 2006, and Lexicon of Arms and Armor from Iran - A Study of Symbols and Terminology, Tübingen, 2010), this volume shifts attention from the material evidence of Persian arms and armour to their combative usage, thus the focus is no longer on the physical characteristics of weaponry but on the ways in which they are brought into action, in addition to fighting methods without accoutrements, such as wrestling. 
2 Beyond doubt, this work may primarily attract the attention of those with an active involvement in historical martial arts, yet it is not a practical manual. Instead, it serves multiple other purposes: as a general introduction to the terminology of techniques; a comparative study of textual/pictorial depictions and living practice; and as a collection of classical Persian treatises in English translation. In the first part, the general principles of knightly traditions (javān-mardī) are tackled, among which the rituals, fighting and performative techniques, training, and paraphernalia of the $z \bar{u}$ rHāne are foremost. The next section discusses archery, from the making of bows and arrows to targeting methods. This part includes three translated texts as well: the chapter on archery of the Nowrūz-nāme of Omar Hayyām, a chapter from an early Safavid manuscript by Šarif Moḥammad, and an entire treatise, the Jām'e al-Hedāyat, of Neẓām al-Dīn Sāvajī, dated 982/1574. Horses and horsemanship, including lassoing, form the subject of the third part in which the relevant chapter from Šarif Mohammad's treatise can also be read. Further chapters of the same work appear in the next two parts of the volume, dealing with lances/spears and swordsmanship, respectively. Sections 6,7 , and 8 , on maces/axes, knifes/daggers, and short swords (qamme and qaddāre), do not include entire treatises, but text references on weapon types and fighting techniques are widely quoted throughout. The last part analyses wrestling, and comprises three Safavid texts, of which the Golkošti-ye Mīr Nejāt, a versified account written by a practitioner deserves attention, considering his nuanced use of technical terms. Like in the entire volume, these terms are not only discussed verbally by Moshtagh Khorasani, but also visualised with the help of several hundred photographs, arranged in sequences, and sometimes supplemented with matching imagery from classical book painting. Apart from their role of contextualizing the study, these photographs pay tribute to illustrated Šāh-nāme manuscripts, effectively turning the sumptuous volume into a modern-day equivalent of the 'Book of Kings', with its almost infinite flow of combat images and dispassionate depiction of victory and defeat.

\section{AUTHORS}

\section{IVÁN SZÁNTÓ}

Eötvös Loránd University, Budapest 